\title{
9 \\ Winning public support for transport reforms
}

\author{
Gary Banks
}

It ought to be remembered that there is nothing more difficult to take in hand, more perilous to conduct, or more uncertain in its success, than to take the lead in the introduction of a new order of things. For the innovator has for enemies all those who have done well under the old conditions, and only lukewarm defenders in those who may do well under the new.

— Niccolo Machiavelli, 1513

The reformer's dilemma has rarely been more eloquently or succinctly put than in Machiavelli's much-cited observation in The Prince. Written half a millennium ago, it shows this problem is neither new nor confined to democracies. That said, more recent experience suggests a corollary to Machiavelli's axiom, which could be expressed in similar terms: there is often nothing easier for a government than to make bad policies, for it can count on strong support from those who profit and little opposition from those who lose.

Many of the policies needing reform today were introduced in precisely such circumstances. Once in place, of course, such policies can become politically very hard to withdraw - and that is the nub of the problem we face today in securing key transport policy reforms. 
Expanding a little, the reality is that, almost by definition, structural reform generally entails losses for some groups. These are typically much more concentrated within the community and individually significant to its members than are the consequent gains from reform, notwithstanding their much larger overall magnitude. It follows that those with most at stake, and therefore having the loudest political voice, will normally be the losers, not the winners from reform. And to those not following things too closely, they have persuasive arguments, including the ability to identify actual workers in specific electorates at risk of losing their jobs and livelihood (the 'phone book' test).

The asymmetries confounding reform do not stop there. Significant ones exist within government itself - notably, the division along sectoral lines of bureaucratic structures. While having departments 'responsible' for such sectors as manufacturing, agriculture and mining, or for certain groups in society or for the environment facilitates policy knowledge and program expertise in such areas, it can lead to fragmented information systems and an inability to see the 'big picture'. Central agencies have a broader remit, but often lack the detailed knowledge to act as an effective policy counterweight.

The automobile industry has traditionally been one of the most successful beneficiaries of this asymmetric political economy favouring government preferment (second perhaps only to the Pharmacy Guild), with workers, bosses and sponsoring departments united in common cause.

If anything, the present political contours are making the conditions for successful reform even tougher than they were. Meaningful reform initiatives (ones that actually live up to the name) are getting harder to contemplate and, especially, consummate. There are a number of interacting forces at work.

A key one relates to what I have been calling 'Washminster'. Changes within our political-bureaucratic structures have seen the balance of power in policy development shifting decidedly from the department (with its technical expertise) to the minister's office. This drift has ironically coincided with a loss of policy capability in ministerial offices as careerist political staffers, often with political aspirations of their own, replace policy experts close to the minister. The consequent ascendancy of politics over policy has been exacerbated by the advent of 'new media', with its insatiable daily need for content that 'sells'. Sensationalism, conflict and 
faux controversy are its currency. This fans the 'oppositionism' that has emerged with a vengeance in our parliaments-for who could reasonably expect to get media attention for agreeing with the government?

There is currently a presumption that politicians should respond immediately to issues, making decisions in time for the daily news cycle. Ministers themselves feel they have to react quickly, if only to preempt a potential opposition attack that might get first run in the media.

The problems are compounded as the modern media machine interacts with increasingly fickle and volatile electorates. Old political loyalties and habit voting have largely broken down. It was once accepted that no more than 10-20 per cent of voters would be 'swingers', with most of the electorate having a fairly enduring sense of party identification (and a significant number being 'rusted on'). Recent surveys and studies suggest that swinging or floating voters may now constitute up to 40 per cent of the electorate. In other words, proportionately more votes are 'up for grabs' than ever before. At the same time, growing affluence and abundant information mean the electorate has more things of concern to them politically. And vested interests have ready access to electronic soapboxes that provide wide reach but little real scrutiny.

\section{Lessons from past structural reform successes}

While the environment just described is undoubtedly a tougher one for reformers than in the past, the obstacles to structural reform have never been trivial. Admittedly, some of the key reforms, such as reducing industry protection, were not technically difficult-and in that sense involved 'low-hanging fruit' - but all faced considerable political hurdles. Indeed, opposition to tariff reform was fierce. The approaches used to secure structural reforms in the past therefore, in my view, remain relevant to our current challenges.

The standout structural reform was the National Competition Policy (NCP), which yielded important gains to the Australian community. In its policy coverage and cross-jurisdictional reach, its achievements were without precedent internationally and it continues to be lauded in forums such as the Organisation for Economic Co-operation and Development (OECD). The NCP was confronted by all the adverse 
political and administrative asymmetries noted previously, as well as the additional complexity of securing agreement among several governments. In enabling the market to occupy areas where competition had previously been excluded, the NCP was essentially seeking to withdraw longstanding 'entitlements'. So how was this achieved?

A Productivity Commission review of the NCP in 2005 came up with three overarching success factors:

- Recognition by governments and oppositions across the country that there was a problem and that changes were needed if Australians were to sustain high standards of living.

- Broad acceptance of the solutions, some of which were quite innovative. The notion of reversing the onus of proof in relation to the competition test-requiring the recipient of a regulatory barrier to make a national interest case for retaining it - was revolutionary in its overturning of historical convention.

- Implementation arrangements gave careful consideration to the structuring of incentives and governance arrangements for implementation, with the National Competition Council central to this architecture.

Each of these could be seen simply as conditions that need to be satisfied for any successful reform. The more fundamental question is how they were satisfied. The commission's report again found three key contributors.

First was the existence of credible evidence and analysis about both the extent of the policy problem and the likely benefits from mooted reforms. While the Hilmer review (1993) was instrumental in this, it had the benefit of earlier inquiries and research by the Industry Commission, the Economic Planning Advisory Commission (EPAC), the Australian Bureau of Agricultural and Resource Economics (ABARE) and other wellrespected independent bodies. These often involved not only research, but also the testing of findings and policy ideas in public forums.

Second, there was strong technical and advisory support within key departments and political offices. I have stated previously that the calibre of senior public servants and ministerial advisors has never been higher than it was in those years. This meant that policy champions had the ear 
of ministers, in advancing the ideas coming out of inquiries or reviews and refined through the bureaucracy. This was reinforced by new coordination processes across ministries and jurisdictions.

Third, and most important, was the quality of political leadership, at both federal and state levels, including the ability to explain and promote the idea of structural reform and the community-wide benefits that would flow from it, notwithstanding the adjustment problems for some. It enabled a compelling narrative to be consistently advocated over a long period. It is not enough to have the right answer (as the opposition Liberal Party's 'Fightback' platform showed). Good policy has to be explained effectively to the public to make a difference. This is, above all, the task of the political leadership.

These elements were all mutually reinforcing. Good process, careful program design, effective leadership and a strong, consistent narrative were the hallmarks of the NCP's success. Expressed in this way, the fact successful outcomes resulted is not surprising. Indeed, the OECD has identified similar factors in the reform successes of a range of countries.

Winston Churchill is said to have remarked that a government should never 'waste a good crisis' as an opportunity to advance hard policy decisions. Australia's reforms had more to do with a well-engineered sense of crisis than the real thing. Former treasurer Paul Keating's famous evocation of a 'banana republic' in a radio interview was one instance (echoing Lee Kwan Yew's equally impactful 'white trash' warning of a few years earlier (Clare 2015)). Similarly, treasurer Peter Costello (2004) was able to convince the public that a looming crisis awaited if we failed to prepare for the 'destiny' of an ageing population. In neither case were existing economic settings in a desperate state, but the ability to project what lay ahead and to provoke public discussion about this and the actions required to avert the problems constituted a compelling reform narrative. (There are other examples I could cite, including Costello's ' $\$ 8$ billion black hole' (Davidson 2005).)

Another feature of successful reform leadership was the ability to anticipate and genuinely address potential adjustment costs. If this factor is ignored, it has the potential to derail reform initiatives. Australians have a deeply ingrained sense of fairness, reflected in welfare entitlements that exceed those in most countries. Reforms bringing community-wide benefits still need to pay attention to the losers, especially redundant workers. The incentive payments to the states and territories were partly predicated 
on providing the fiscal wherewithal for this. In addition-and apart from the general safety nets - programs for retraining or relocation were devised in conjunction with the reforms. (It has to be said though that the reality fell somewhat short of the rhetoric, which, in the end, arguably inhibited the full implementation of the NCP agenda.)

\section{Is transport reform tougher?}

These observations about the success factors in the NCP provide a long, but hopefully relevant, introduction to the question of 'winning support for transport reform'. The transport policy reform agenda is very similar to that of the NCP itself. It involves questions of governance and asset management, the structures for funding and user charging and the extent to which governments retain equity and control. It is also about reducing regulation that is anticompetitive or otherwise raises costs or inhibits productivity. And, looking to the future, it is about securing a better basis for informing investment decisions, particularly in relation to allocation and timing.

If the transport reform agenda is indeed comparable to national competition policy reform, one might ask why more headway has not been made? After all, there have been several public inquiries and reviews making a cogent case for reform, akin to the Hilmer review, including some by the Productivity Commission, as well as a number of special taskforces. We have also seen considerable high-level government attention being paid to the issues, particularly in relation to funding aspects. And we briefly even had a prime minister proclaiming himself 'the infrastructure prime minister' (Abbott 2013).

Yet, spending aside, we have seen less progress on the structural reform dimensions than in other areas of public infrastructure: less governance reform (with most entities still embedded in departmental structures), less contestability and less cost-reflective pricing. Understanding why that is so is obviously the key to moving forward. It seems unlikely it is because transport is an inherently more complex policy area than, say, energy, water or telecommunications, as anyone familiar with telecommunications would attest for a start. But if not technically more complex, could it be said that the politics are more challenging? 
In considering the political dimensions, it is useful to examine the potential 'blockers' to specific reforms. Unsurprisingly, the 'usual suspects' loom large.

For a start, when it comes to reforming governance arrangements (corporatisation, privatisation or even commercialisation), politicians, existing provider organisations, the unions and consumers each have their own concerns about loss of control or loss of income, or both.

In the regulatory space, as noted, incumbents can be expected to oppose regulatory changes that will increase competitive pressures. And labour unions often resist moves to enhance organisational 'flexibility' as code for loss of entitlements.

Vested interests typically pursue objectives other than efficiency for capital spending. And governments themselves tend to be attracted less to smaller bottleneck investments - even those with a high pay-off-than to higher-profile greenfield projects.

But the strongest opposition has arisen in relation to user charging for roads. Traditionally, the public has seen roads as a free good, funded through less transparent fuel excise and other taxation, rather than direct pricing. So proposals to introduce cost-reflective pricing are bound to face broad opposition, particularly from those paying more as a result.

The obstacles to these reforms, while challenging, are not so different to those for other areas of infrastructure that progress should not be possible. Even in the most challenging area of road pricing, users are becoming accustomed to the principle of 'user pays' from moves in other service areas (such as water) and have clearly accepted the logic for toll roads. And, given roads are not really 'free' anyway, making a compelling case for moving to a more efficient way of paying for them, provided arrangements can be shown to be 'fair', should not be so hard. Indeed, considerable headway has already been made, with reports by the Productivity Commission and Infrastructure Partnerships Australia showing the way forward. At least the technological hurdles are now surmountable, such that charging based on where and when a vehicle actually uses the road network can be accurately determined. Provided there can be some assurance that resulting revenue will flow into improved road services (admittedly no simple matter institutionally), support from business at least could be assured. 


\section{Advancing the transport reform agenda}

The biggest challenges currently have more to do with the general deterioration in the climate for structural reforms, described earlier. While these may call for new tactics and tools, the broad approach that worked so well for us in the past should remain central. The dual preconditions for success remain securing broad agreement on why reform is needed and on the reforms that will deliver the greatest public value.

Too often in recent times governments have sought to truncate this twostep process, pursuing the 'what' before ensuring the 'why' is understood and accepted. Admittedly, building public understanding of the need for change can be difficult. It cannot be achieved overnight. It requires persistence and repetition. (Former prime minister John Howard recently remarked in an interview that 'a treasurer must be in the media every day ... Making the case for change, being one of the government's most effective communicators' (Bowen 2014).)

Arm's-length policy reviews can provide crucial support. In particular, credible independent estimates of the costs of the status quo and of the gains from reform constitute handy rhetorical assets for a government. Compared with the earlier Hilmer review process, however, it is not clear that more recent reviews in the transport area have done enough to convince people there is a real problem. Or, perhaps more accurately, it is not clear that governments have taken sufficient advantage of the opportunity they presented to make a compelling case.

Only once the need for change is broadly accepted can specific reform proposals be effectively prosecuted. These need to lay out not only the gains from change, but also the likely incidence of both gains and losses, whether the latter would be mitigated in some way and, if not, why not. The public will focus on the losers (encouraged by the media and the losers themselves) and will ultimately make a judgement about whether the proposed reforms seem fair. This is more likely to the extent that reform processes have allowed people to voice their concerns and whether the government is judged to have listened. (Listening is often more important in the end than whether the government actually agrees.)

Because there is always an element of uncertainty as well as disruption in any significant reform proposal, the public will naturally be risk-averse. Pilot projects and the phasing in of initiatives can help allay concerns, 
as well as pointing to potential design improvements ahead of a wider rollout. (We heard the instructive example of Sweden, where road pricing was widely opposed at the outset, but, following a carefully staged implementation process, eventually received a 70 per cent approval rating from the public.)

In Australia, there is of course the additional difficulty of securing acceptance and agreement across our federation. Previous examples of reforms that have stalled or failed have often arisen because there has not been agreement about the problem or the proffered solution (or both) in the first place. In some cases, a federal government has sought to proceed without properly consulting the states. The outcome in most such cases, unsurprisingly, has been failure. It should be obvious therefore that much transport reform, particularly road pricing, stands no chance without securing collaboration and cooperation across jurisdictions.

\section{Summing up}

To conclude, desirable transport reform is challenging-for reasons I have outlined — and it would be easy to become pessimistic about its prospects. But the specific challenges are not really more daunting than in some other areas of infrastructure reform. And much good work establishing the case for reform has already been done.

The real question is whether political leaders are up to the task, in an environment that has become ever more challenging for far-sighted reform. There is mounting evidence that they are not; however, there are also a few shards of light in the gloom. For example, the fact the most recent NSW election was essentially fought on an important infrastructural reform issue, and that the government managed to prevail notwithstanding orchestrated opposition from 'the usual suspects', provides some grounds for optimism. Then there is the impressive reformist record of the previous New Zealand Government, which, contrary to Jean-Claude Juncker's aphorism, not only knew what to do, but also managed to get re-electednot once, but twice. The New Zealand experience reinforces the lessons from Australia's own past, that the key to governments winning public support is a credible and well-argued case that reforms will actually make life better for a country's citizens. That does not seem too much to ask. 


\section{References}

Abbott, T. (2013). Tony Abbott's campaign launch speech: full transcript. 25 August. Brisbane. Available from: www.smh.com.au/politics/federal/tonyabbotts-campaign-launch-speech-full-transcript-20130825-2sjhc.html

Bowen, C. (2014). The Money Men: Australia's Twelve Most Notable Treasurers. Melbourne: Melbourne University Press.

Clare, J. (2015). Why Australia is in danger of becoming Asia's digital banana republic. Business Insider, 24 October. Available from: www.businessinsider. com.au/why-australia-is-in-danger-of-becoming-asias-digital-bananarepublic-2015-10

Costello, P. (2004). Speech: Australia's demographic challenges. 25 February. Marriott Hotel, Sydney. Available from: www.petercostello.com.au/ speeches/2004/2066-australia-s-demographic-challenges

Davidson, K. (2005). A charter of budget dishonesty. The Age, June 9. Available from: www.theage.com.au/news/Kenneth-Davidson/A-charter-of-budget-dis honesty/2005/06/08/1118123894921.html

Hilmer, F. G., Rayner, M. R. and Taperell, G. Q. (1993). National Competition Policy: Report by the Independent Committee of Inquiry. Canberra: Commonwealth of Australia. Available from: ncp.ncc.gov.au/docs/ National\%20Competition\%20Policy\%20Review\%20report,\%20The\%20 Hilmer\%20Report,\%20August\%201993.pdf

Machiavelli, N. (1988). The Prince, ed. Quentin Skinner and Russell Price. Cambridge; New York: Cambridge University Press.

Productivity Commission. (2005). Review of National Competition Policy Reforms: Productivity Commission Inquiry Report. Canberra: Productivity Commission. Available from: www.pc.gov.au/inquiries/completed/national-competitionpolicy/report/ncp.pdf 
This text is taken from Road Pricing and Provision: Changed Traffic Conditions Ahead, edited by Michael de Percy and John Wanna, published 2018 by ANU Press, The Australian National University, Canberra, Australia.

doi.org/10.22459/RPP.07.2018.09 